\section{International Scientific Journal Theoretical \& Applied Science}

\author{
p-ISSN: 2308-4944 (print) e-ISSN: 2409-0085 (online) \\ Year: 2014 Issue: 12 Volume: 20 \\ Published: $30.12 .2014 \quad$ http://www.T-Science.org
}

SECTION 8. Architecture and construction.
Meyrbek Inkarbekuly Azbergen

Professor, candidate of technical Sciences,

Taraz state University named after M.Kh. Dulati,

Kazakhstan

azmeirbek@mail.ru

\section{Alexandr Nikolayevich Shevtsov}

candidate of technical sciences, corresponding member of the Kazakhstan

National Academy of Natural Sciences,

Member of Publishers International Linking Association (USA), Department of «Mathematics», Deputy Director on Science of FITAT, Taraz state University named after M.Kh. Dulati, Kazakhstan $\underline{\text { Shev_AlexXXXX@mail.ru }}$

\title{
DISPERSED-PHASE SOIL MODEL AND GIVEN THE FREQUENCY OF LOADING
}

Abstract: In the article the method of calculating the deformation of the soil under buildings using the model of dispersed-phase medium, the porosity which is defined through the volumetric strain in triaxial compression. The proposed method of calculation allows to take into account the repeated application of a cyclic load.

Key words: the soil model, the coefficient of porosity, volumetric strain, cyclic load.

Language: English

Citation: Azbergen MI, Shevtsov AN (2014) DISPERSED-PHASE SOIL MODEL AND GIVEN THE FREQUENCY OF LOADING. ISJ Theoretical \& Applied Science 12 (20): 94-96. doi: http://dx.doi.org/10.15863/TAS.2014.12.20.20

The effectiveness of the design and operational reliability of buildings and structures are largely determined by the reliability of the forecast precipitation of their bases. Calculation methods used in this case, as a rule, are based on data from experimental studies of soils and require constant improvement.

The bottoms of the bases of buildings and constructions, built on a slab Foundation, working under triaxial compression. For such structures the calculations precipitation grounds can be performed using the model disperse-phase environment.

According to the model of dispersed-phase medium [1-4] solid mineral particles that make up the soil skeleton and the pore water is absolutely incompressible. Mechanical particles skeleton interact only at the sites of contact, and any deformation of the soil is considered to be the result of their relative displacements. Volume compression (compaction) of the soil leads to the decrease of pore volume per unit volume and an increase in the content of the solid phase. Therefore, the volumetric strain of the soil necessary to predict rainfall ground, can be calculated by changing their phase characteristics.

It is easy to imagine that the volume of solid particles of a soil element before compression is

$$
V_{s k, o}=A h_{o} \frac{1}{1+e_{o}},
$$

and after compression

$$
V_{s k, i}=A\left(h_{o}-S\right) \frac{1}{1+e_{i}},
$$

$h_{o}$ - the initial height of the soil element;

$A$ - the cross-sectional area of the soil element;

$e_{o}$ - the initial porosity coefficient of the substrate;

$e_{i}$ - the coefficient of porosity after compression;

$S$ - sediment soil element under compression is compression.

Because of the dispersed-phase model of solid particles are incompressible, their volume in a soil element under compression will remain constant. Then, by equating the right hand sides of the expressions (1) and (2), we obtain

$$
h_{o} \frac{1}{1+e_{o}}=\left(h_{o}-S\right) \frac{1}{1+e_{i}},
$$

hence the dependence of the binding of soil sediment is changing the compression ratio of porosity:

$$
S=\frac{e_{o}-e_{i}}{1+e_{o}} h_{o}
$$

When calculating precipitation under buildings coefficients $e_{o}$ and $e_{i}$ in the expression (4) represent, 
respectively, the porosity of a soil element, condensed from the stress of their own weight of soil $\sigma_{z g}$ after application of additional vertical pressure $\sigma_{z p}$. For the i-th soil layer the Foundation of the porosity can be defined as

$$
\begin{aligned}
& e_{o(i)}=\frac{\rho_{s(i)}}{\rho_{d(i)}}\left(1-\varepsilon_{v o(i)}\right)-1 ; \\
& e_{(i)}=\frac{\rho_{s(i)}}{\rho_{d(i)}}\left(1-\varepsilon_{v(i)}\right)-1,
\end{aligned}
$$

$\rho_{s(i)}, \quad \rho_{d(i)}$ - density of soil particles and the density of the dry soil of the i-th base layer; $\varepsilon_{v o(i)}, \quad \varepsilon_{v(i)}$ - volumetric strain of the soil of the ith base layer from the action of their own weight and after application of the additional load.

Substituting the values of the coefficients of porosity from expressions (5) and (6) in (4) and after a simple transformation, we can write an expression to determine rainfall ground in the following form:

$$
S=\sum_{i=1}^{n} \frac{\varepsilon_{v(i)}-\varepsilon_{v o(i)}}{1-\varepsilon_{v o(i)}} h_{(i)} .
$$

The volumetric strain of the soil corresponding to the conditions of triaxial compression, defined as [5-9]

$$
\begin{gathered}
\varepsilon_{v o(i)}=\frac{\sigma_{z g(i)}(1+2 \xi)}{3 a+b \sigma_{z g(i)}(1+2 \xi)} \\
\varepsilon_{v(i)}=\frac{\left(\sigma_{z g(i)}+\sigma_{z p(i)}\right)(1+2 \xi)}{3 a+b\left(\sigma_{z g(i)}+\sigma_{z p(i)}\right)(1+2 \xi)},
\end{gathered}
$$

$\xi$ - the lateral pressure coefficient;

$\mathrm{a}, \mathrm{b}$ - experimental parameters. If the base is composed of different layers of soil, which often occurs in practice, the parameters obtained by testing each of them separately.

When calculating the settling of foundations of buildings and structures exposed to cyclic load, the volumetric strain derived from the sum of two strains:

$$
\varepsilon_{v(i N)}=\varepsilon_{v(1)}+\Delta \varepsilon_{v(i N)} .
$$

Additional volumetric strain at $\mathrm{N}$ cycles of loading is defined as

$$
\Delta \varepsilon_{v(N)}=\Delta \varepsilon_{v(1)}\left(1+B_{v} \ln N\right),
$$

$B_{v}$ - experimental setting.

The amount of additional plastic volumetric deformation from the first loading cycle $\left(\Delta \varepsilon_{v(1)}\right)$ on the results of the experiments are well approximated by the expression [10]

$$
\Delta \varepsilon_{v(1)}=\alpha_{v}(\sigma)^{\beta_{v}} \ln \left(n / n_{o}\right),
$$

$\sigma$ - medium pressure;

$\alpha_{v}, \quad \beta_{v}, n_{o}-$ experimental parameters; $n=\sigma^{u} / \sigma^{c m}$ - the degree of unloading;

$\sigma^{c m}$ - the total pressure;

$\sigma^{u}$ - the cyclical component of the mediumpressure.

The proposed method of calculating the base using a dispersed-phase model of the soil will increase the reliability of the forecast precipitation of buildings and structures under cyclic effects, which will lead to lower operating costs.

\section{References:}

1. Gol'dshteyn MN (1979) Mekhanicheskie svoystva gruntov. - Moscow: Stroyizdat, 1979. $-304$.

2. Gol'dshteyn MN, Tsar'kov AA, Cherkasov II (1981) Mekhanika gruntov, osnovaniya i fundamenty. - Moscow: Transport, 1981. -320.

3. Tsytovich NA (1983) Mekhanika gruntov. Moscow: Vysshaya shkola, 1983. -288.
4. Ivanov PL (1985) Grunty i osnovaniya gidrotekhnicheskikh sooruzheniy. - Moscow: Vysshaya shkola, 1985. -352.

5. Azbergen MI (1986) Raschet osadok osnovannyy metodom posloynogo summirovaniya s prime $\neg$ neniem EVM BESM-6 / Metodicheskaya razrabotka $\mathrm{k}$ vypolneniyu NIRS.- Moscow: MISI, 1986. -46. 
6. Zaretskiy Y.K, Vorontsov EI, Azbergen MI (1987) Inzhenernyy metod rascheta osadki osnovaniy pri staticheskikh i tsikli $\neg$ cheskikh nagruzkakh. Bibliograf. ukazatel' VINITI/ Deponirovannye nauchnye raboty, №1 .Moscow: 1987. -17 .

7. Azbergen MI (1997) Nelineynaya deformiruemost' gruntov i uchet povtornosti nagruzheniya. Almaty: Gylym, 1997. -96.

8. Azbergen MI (2001) Deformatsii gruntov pri trekhosnom szhatii (na kazakhskom yazyke)
/Uchebnoe posobie.- Karatau: RITs AGTU, 2001. -112.

9. Azbergen MI (2012) Nekotorye voprosy geotekhniki. - Almaty: Evero, 2012. -116.

10. Vorontsov EI, Azbergenov MI (1987) Otsenka vliyaniya tsiklicheskogo nagruzheniya peschanykh gruntov na ikh deformatsiyu / Sb. nauchnykh trudov Gidroproekta, vyp. 124. Moscow: 1987. - pp.141-147. 